Nowoczesne Systemy Zarządzania

Zeszyt 12 (2017), nr 1 (styczeń-marzec)

ISSN 1896-9380, s. 201-220

Modern Management Systems

Volume 12 (2017), No. 1 (January-March)

ISSN 1896-9380, pp. 201-220
Instytut Organizacji i Zarządzania

Wydział Cybernetyki

Wojskowa Akademia Techniczna

w Warszawie

Institute of Organization and Management

Faculty of Cybernetics

Military University of Technology

\title{
Program Mieszkanie Plus jako istotny czynnik reformy polityki mieszkaniowej i aktywizacji wzrostu gospodarczego w sektorze publicznym w Polsce
}

\section{Apartment Plus program as an important factor for reforming housing policy and stimulating economic growth in the public sector in Poland}

\author{
Dariusz Prokopowicz \\ e-mail: darprokop@poczta.onet.pl \\ Wioletta Wereda \\ Wojskowa Akademia Techniczna \\ Wydział Cybernetyki \\ e-mail: weredawioletta@tlen.pl
}

Uniwersytet Kardynała Stefana Wyszyńskiego w Warszawie

\begin{abstract}
Abstrakt: Uruchomiony w kwietniu 2016 roku program Rodzina 500 Plus znacznie zmniejsza skalę niekorzystnego społecznie i ekonomicznie zjawiska, tj. dotychczasowej najniższej dochodowości w rodzinach wielodzietnych. Kolejnym kluczowym programem społecznej polityki rodzinnej w Polsce, uruchomionym w grudniu 2016 roku, jest program Mieszkanie Plus. Program ten także powinien analogicznie pozytywnie wpłynąć na sytuację mieszkaniową, zmniejszając rozwarstwienie społeczne. Głównym celem programu Mieszkanie Plus jest znaczące zwiększenie dostępności mieszkań w Polsce, a szczególnie tanich mieszkań czynszowych, z możliwością wykupienia własności. Konsekwencją rozwinięcia tego programu na większą skalę, w kolejnych latach, będzie zaoferowanie takich mieszkań przede wszystkim dla rodzin, które do tej pory nie miały możliwości ich wynajmu i zakupu, ze względu na niskie dochody i brak zdolności kredytowej. Jeżeli przyjęty przez rząd plan rozwinięcia w kolejnych latach programu Mieszkanie Plus zostanie zrealizowany, to do 2030 roku poziom dostępności mieszkań dla obywateli w Polsce osiągnie poziom zbliżony do średniej w Unii Europejskiej.

Słowa kluczowe: program Mieszkanie Plus, sytuacja mieszkaniowa, dostępność mieszkań, mieszkania na wynajem, sytuacja materialna, Narodowy Program Mieszkaniowy, rodzina, gospodarstwo domowe, społeczeństwo, polityka rodzinna, polityka społeczna, polityka mieszkaniowa, polityka gospodarcza, dochody, oszczędności, konsumpcja, Bank Gospodarstwa Krajowego Nieruchomości, program Rodzina 500 Plus
\end{abstract}


Abstract: Launched in April 2016, the 500 Plus family program significantly reduces the scale of socially and economically disadvantageous phenomena, i.e. the current lowest rates in families of many. Another key program of social family policy in Poland launched in December 2016 is the Apartment Plus program. This program should also have a positive impact on the reduction of social degradation in the housing situation. The main objective of the Apartment Plus program is a significant increase in the availability of housing in Poland, especially low-cost housing with the possibility of buying out properties. The consequence of the development of this program on a larger scale in the coming years will be to offer such housing primarily to families who have so far been unable to rent and purchase housing due to their low incomes and lack of creditworthiness. If a government-approved development plan for the subsequent years of the Apartment Plus program will be implemented by 2030, the level of housing availability for citizens in Poland will reach a level close to the average in the European Union.

Keywords: Apartment Plus program, housing situation, housing availability, housing for rent, financial situation, National Housing Programme, family, household, society, family policy, social policy, housing policy, economic policy, income, savings, consumption, Bank National Real Estate Holding, Family Plus 500 program

\section{Wprowadzenie}

Do podstawowych potrzeb bezpieczeństwa człowieka zalicza się sferę rodzinną i mieszkaniową. Kwestia mieszkaniowa jest również jednym z kluczowych aspektów sytuacji materialnej obywateli danego kraju. Od początku transformacji społeczno-gospodarczej, tj. od początku lat 90. nastąpiły znaczące zmiany sytuacji mieszkaniowej, co zdeterminowane było społeczno-gospodarczymi uwarunkowaniami polityki mieszkaniowej w Polsce (Bywalec, 2012, s. 36).

Celem zwiększenia efektywności działania reform kluczowych segmentów polityki społeczno-gospodarczej istotna jest kompleksowość i skorelowanie celów i instrumentów tych reform. W związku z tym do obecnie realizowanego programu Rodzina 500 Plus rząd dodawać będzie kolejne segmenty reform polityki społeczno-gospodarczej, w tym także rodzinnej polityki społecznej (Rogala, 2016, s. 36). Następnym istotnym segmentem rodzinnej polityki społecznej, który także na tak dużą skalę nie był w Polsce od 1989 roku realizowany jest program wsparcia polskich rodzin w kwestii zabezpieczenia najbardziej elementarnej, podstawowej potrzeby bytowej, egzystencjalnej, tj. kwestii mieszkaniowej, co potocznie określamy posiadaniem „dachu nad głową”. Jest to kluczowy determinant, który warunkuje wśród młodych obywateli naszego kraju podjęcie decyzji o założeniu rodziny i posiadaniu dzieci (Tyszka, 2001, s. 38).

Ze statystyk wynika, że Polska jest na końcu w rankingach na tle Europy pod względem dostępności i ilości tanich mieszkań pod wynajem. Przedstawiony przez rząd w maju i uruchomiony w grudniu 2016 roku program Mieszkanie Plus ma zmienić te niechlubne statystyki w perspektywie kilku kolejnych lat (Programy, 2015). W Polsce nie realizowano od 1989 roku tego typu programu. Na uruchomienie procesu realizacji tego typu kompleksowych programów gospodarczych potrzeba minimum kilku lat i taki okres jest uwzględniony do uruchomienia pełnych mocy wytwórczych w obecnych planach rządu. Mimo tego, że pierwsze mieszkania z tego programu mają być oddane do użytku już na początku 2018 roku to jednak od 
etapu uruchomienia programu $\mathrm{w}$ grudniu 2016 roku, rozwoju etapu inwestycyjnego, aż do pojawienia się w gospodarce pozytywnych efektów aktywizacji wzrostu gospodarczego, prawdopodobnie minie kilka lat. Program ten powinien znacząco zwiększyć dostępność mieszkań dla rodzin w Polsce i zbliżyć pod tym względem warunki mieszkalnictwa, szczególnie w zakresie tanich mieszkań pod wynajem wobec standardów krajów Zachodniej Europy. Sytuacja ta od początków transformacji systemowej w Polsce, tj. od roku 1989, wymagała podjęcia radykalnych kroków celem przeprowadzenia reformy systemu budownictwa osiedli mieszkaniowych, w tym tanich mieszkań czynszowych (Jewdokimow, 2011, s. 136).

\section{Sytuacja mieszkaniowa w Polsce}

Zasadniczym źródłem danych, które posłużyły w określeniu sytuacji mieszkaniowej w latach ubiegłych były wyniki narodowych spisów powszechnych, stanowiące także podstawę dla zestawień analitycznych i badań porównawczych zawartych w opracowaniach wydawanych przez Główny Urząd Statystyczny. Głównym źródłem danych na potrzeby przeprowadzanych analiz są wyniki Narodowych Spisów Powszechnych uzupełniane bieżącą statystyką GUS-u.

Dane statystyki narodowej jednoznacznie wskazują na znaczące zróżnicowanie sytuacji mieszkaniowej dotyczące skali Polski, z uwzględnieniem podziału miasto-wieś, podziału regionalnego oraz kwestii poziomu dochodów obywateli. Dane te przedstawiają także istniejący permanentnie strukturalny kryzys mieszkaniowy, którego źródła historycznie sięgają okresu sprzed 1989 r. i który związany jest transformacją systemową lat 90. i pogłębiony po 2008 r. globalnym kryzysem finansowym (Prokopowicz, 2010, s. 147). Przed wspomnianym kryzysem ceny nieruchomości przez kilka lat dynamicznie pięły się w górę, co było wynikiem promocyjnej polityki kredytowej banków komercyjnych (Domańska-Szaruga, 2015, s. 95), które obniżyły poziom wymaganej zdolności kredytowej dla kredytobiorców zaciągających kredyty we franku szwajcarskim CHF na cele mieszkaniowe bądź budowlane. Była to celowa polityka nakręcania koniunktury na rynku budowlanym i mieszkaniowym przez banki komercyjne (Dmowski, Prokopowicz, Samowski, 2008, s. 142), które wraz z zagranicznym kapitałem przeniosły do Polski swe praktyki stosowane wcześniej np. w Hiszpanii czy Grecji, czym doprowadziły do pogłębienia kryzysu gospodarczego w tych krajach (Domańska-Szaruga, 2013, s. 262-263).

Ceny nieruchomości znacząco wzrosły w okresie lat 2000-2008, w niektórych miastach uległy co najmniej podwojeniu przy znacznie mniejszym wzroście wynagrodzeń obywateli. Po pojawieniu się na jesieni 2008 roku globalnego kryzysu finansowego i gdy efekty tego kryzysu makroekonomicznie i transgranicznie dotarly do polskiej gospodarki, wówczas tempo wzrostu gospodarczego w Polsce uległo znaczącemu zmniejszeniu, a poziom wynagrodzeń nie wykazywał tendencji wzrostowej 
(Gwoździewicz, Prokopowicz, 2016, s. 65). Zdarzały się niejednokrotnie sytuacje, w których pracodawcy zmniejszali pracownikom poziom wynagrodzeń motywując te działania pojawiającym się wówczas spowolnieniem wzrostu gospodarczego w Polsce, który był efektem wtórnym globalnego kryzysu finansowego (Prokopowicz, 2016a, s. 14-15). W takiej sytuacji w okresie dekady lat 2000-2010 możliwości zakupu mieszkania przez obywateli, biorąc pod uwagę spadającą relację dochodów względem cen mieszkań, uległy znaczącemu obniżeniu. Pokryzysowe spowolnienie wzrostu gospodarczego dotyczy w różnym stopniu także innych krajów w Europie. W związku z tym pojawia się potrzeba poszukiwania nowych formuł polityki rozwoju sektora mieszkaniowego, co jest szczególnie istotne w kontekście trwałego zrównoważonego rozwoju, stanowiącego kluczowy czynnik postępu w ogólnym rozwoju cywilizacyjnym oraz istotny determinant wzrostu gospodarczego każdego kraju (Prokopowicz, 2016b, s. 21-22).

$\mathrm{Z}$ drugiej strony analiza danych GUS przeprowadzona dla okresu wieloletniego pozwoliła na wykazanie także innych trendów skorelowanych z sukcesywnie poprawiającą się sytuacją ekonomiczną krajowej gospodarki i wzrostu zamożności rodzin w Polsce. Na poniższym wykresie przedstawiono zmianę struktury poszczególnych rodzajów budynków zamieszkiwanych przez rodziny w Polsce w latach 2005 i 2015. W okresie tym odnotowano 4 proc. spadek udziału rodzin mieszkających w budynkach wielorodzinnych (do 55,2 proc.). Z drugiej strony w okresie lat 2005-2015 na podstawie analizy danych GUS wykazany został 3 proc. wzrost zamieszkiwania przez rodziny w Polsce w domach jednorodzinnych wolnostojących (do 38,4 proc. w 2015 roku) oraz w domach jednorodzinnych w zabudowie szeregowej lub bliźniaczej, w których wzrost kształtował się już na znacznie niższym poziomie 1 proc. (do 6,2 proc. w 2015 roku) (Łysoń, 2016, s. 65).
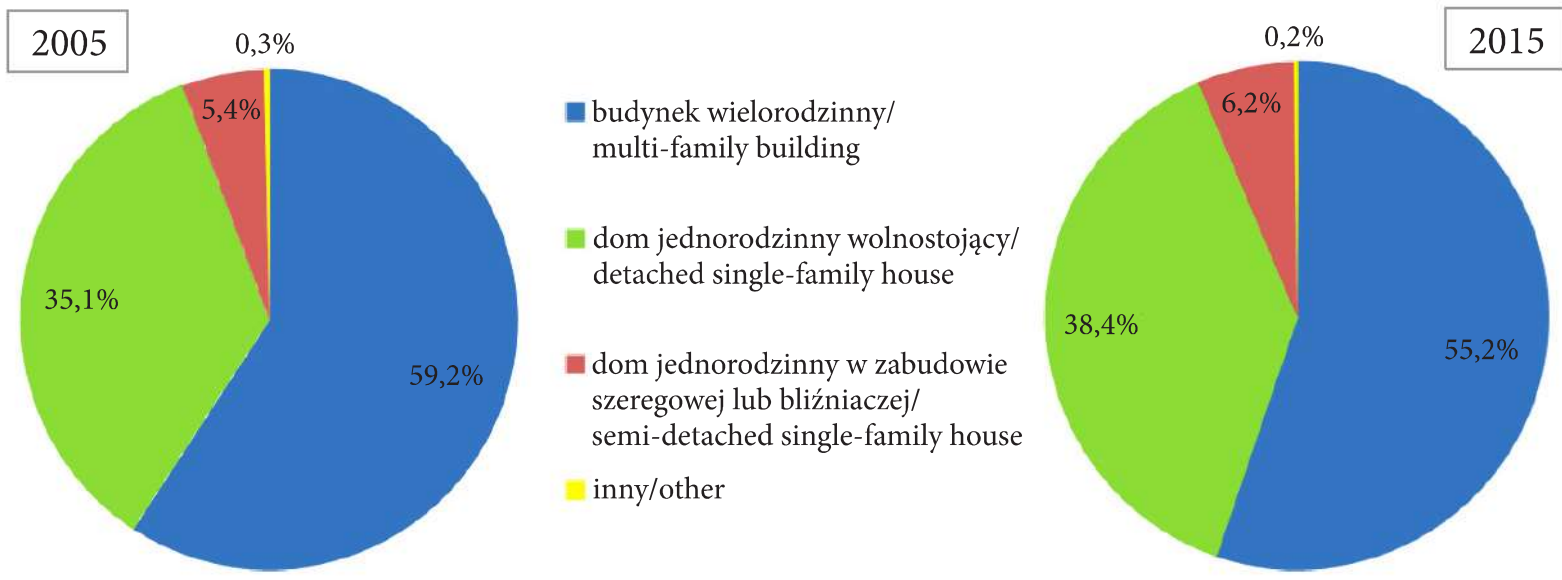

Wykres 1. Gospodarstwa domowe zamieszkujące poszczególne rodzaje budynków w 2005 i 2015 roku

Źródło: P. Łysoń, 2016, s. 65 
Podobny, aczkolwiek nieco inny, obraz sytuacji mieszkaniowej w tej kwestii przedstawiają wyniki badań ankietowych przeprowadzonych przez Główny Urząd Statystyczny na gospodarstwach domowych i ich członkach, tj. Europejskiego badania warunków życia (EU-SILC) oraz na podstawie przeprowadzonego w 2011 roku Narodowego Spisu Powszechnego.

Według wyników tych badań prawie połowa, tj. 45,2 proc. rodzin w Polsce w 2011 roku zamieszkiwała $w$ wolnostojących domach jednorodzinnych. Niewiele mniej rodzin w Polsce, tj. 40,1 proc. zamieszkiwało bloki lub kamienice, czyli budynki wielorodzinne składające się z minimum 10 lokali mieszkalnych. Analogiczne budynki posiadające mniej niż 10 lokali mieszkalnych zamieszkiwała już tylko co dziesiąta rodzina w Polsce (9,9 proc.). Najmniej ponieważ tylko 4,6 proc. gospodarstw rodzinnych mieszka w domach jednorodzinnych w zabudowie szeregowej w tym w tzw. „bliźniakach”(GUS, 2014, s. 53).

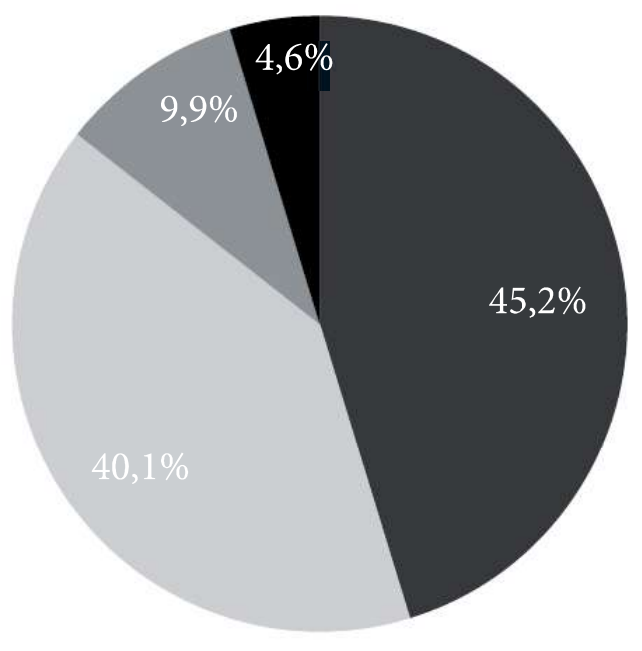

-W domu jednorodzinnym wolnostojącym

W budynku z 10 lub więcej lokalami mieszkalnymi

W budynku z mniej niż 10 lokalami mieszkalnymi

-W domu jednorodzinnym w zabudowie szeregowej (również bliźniak)

Wykres 2. Rodzaj zamieszkiwanego budynku

Źródło: GUS, 2014, s. 51

Na podstawie przytoczonych wyników badań określona została także kwestia tytułu prawnego do użytkowania mieszkania przez określone rodzaje gospodarstw domowych w Polsce (duzarodzina.pl 2015). W Polsce dominuje użytkowanie lokali mieszkalnych na podstawie uregulowanych normatywnie tytułów własności do tych lokali, ponieważ aż 82 proc. rodzin zamieszkiwało lokal, który był ich własnością lub gospodarstwo domowe było w posiadaniu spółdzielczego własnościowego prawa do tego lokalu. $Z$ drugiej strony znacząca część, tj. 10,9 proc. $z$ tych lokali własnościowych obciążona była kredytem hipotecznym (GUS, 2014, s. 53).

Pozostała, relatywnie nieduża część rodzin w Polsce zamieszkiwała lokale, które nie były ich własnością. Zamieszkiwane lokale mieszkalne bez prawa własności, w zakresie których zaliczono głównie lokale komunalne, socjalne lub służbowe, stanowiły 8,4 proc. całokształtu gospodarstw domowych w Polsce. W kontekście 
standardów krajów Europy Zachodniej stosunkowo niewielka część rodzin w Polsce - tylko 5,5 proc. - wynajmuje zamieszkiwane lokale bez posiadania do nich jakichkolwiek praw własności. Poza tym tylko 3,2 proc. gospodarstw rodzinnych zamieszkiwało lokale, do których posiadały normatywnie uregulowane spółdzielcze lokatorskie prawo do zajmowanego lokalu (Cesarski, 2016, s. 231).

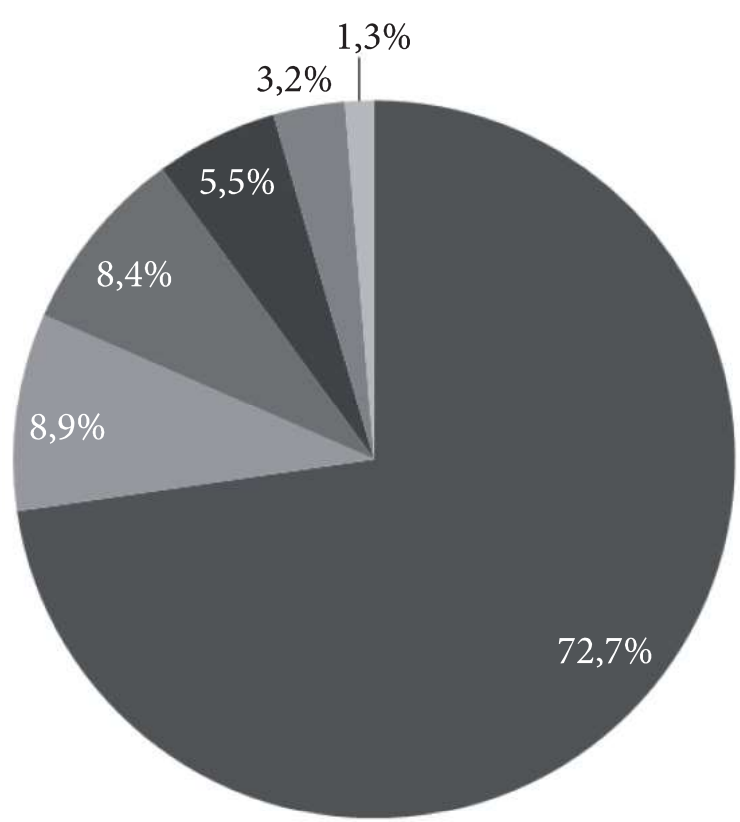

- Własność nieobciążona kredytem hipotecznym na zakup użytkowanego mieszkania (lub spółdzielcze własnościowe)

* Własność obciążona kredytem hipotecznym na zakup użytkowanego mieszkania (lub spółdzielcze własnościowe)

- Bez opłat za najem (komunalne, socjalne lub służbowe)

- Najem lub podnajem (według cen rynkowych lub poniżej)

- Spółdzielcze lokatorskie prawo do lokalu

Inny

Wykres 3. Tytuł prawny z jakiego użytkowane jest mieszkanie (w 2011 r.)

Źródło: GUS, 2014, s. 53

Sytuacja mieszkaniowa rodzin w Polsce jest znacząco zróżnicowana także $\mathrm{w}$ kwestii powierzchni użytkowanych lokali mieszkalnych. Z przeprowadzanych analiz porównawczych różnych typów gospodarstw rodzinnych wynika, że zróżnicowanie w tym zakresie jest wysokie, ponieważ użytkowana powierzchnia mieszkalna waha się w zakresie od kilkunastu do kilkuset metrów kwadratowych (Rachucki, 2014). W 2011 roku średnia powierzchnia lokalu mieszkalnego użytkowanego przez rodzinę w Polsce wyniosła $82 \mathrm{~m}^{2}$. Z danych GUS wynika, że występuje znaczące zróżnicowanie w zakresie powierzchni użytkowanych lokali mieszkalnych, gdy porówna się średnie powierzchnie tych lokali zamieszkiwane przez rodziny na wsi i w miastach. Średnia powierzchnia lokali mieszkalnych użytkowanych przez gospodarstwa rodzinne na wsi wynosiła ok. $100 \mathrm{~m}^{2}$ i była o $30 \mathrm{~m}^{2}$ większa w porównaniu z lokalami zamieszkiwanymi przez rodziny w miastach (GUS, 2014, s. 54).

Z przeprowadzonych badań wynika, że posiadane i zajmowane powierzchnie mieszkalne są skorelowane z poziomem dochodowości rodzin w Polsce. Relatywnie niższe dochody osiągali samotni rodzice wychowujący minimum 1 dziecko. 


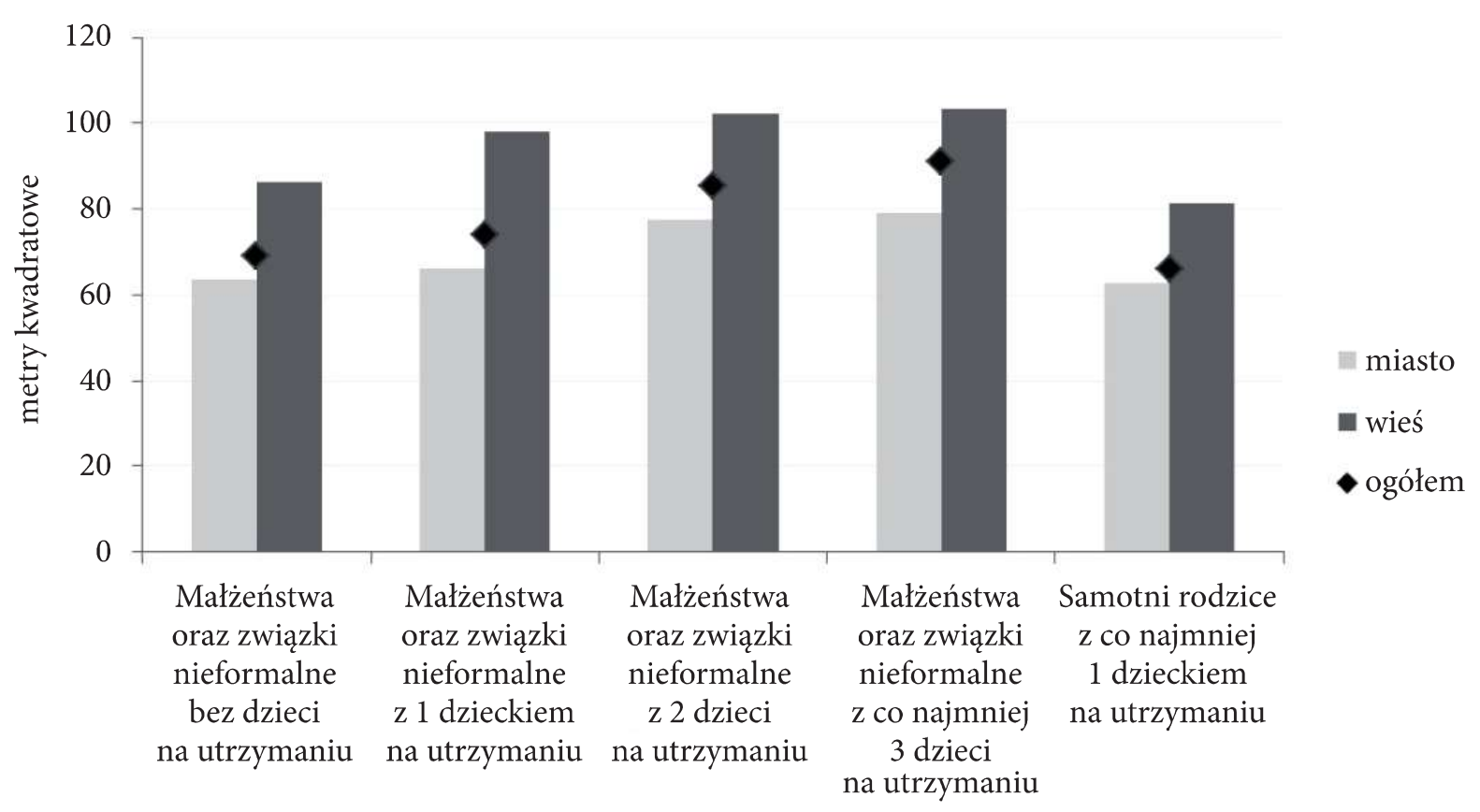

Wykres 4. Średnia powierzchnia mieszkania według typu gospodarstwa rodzinnego w mieście i na wsi

Źródło: GUS, 2014, s. 54

Prowadzone przez nich gospodarstwa domowe zajmowały średnio najmniejszą powierzchnię mieszkalną, tj. $66 \mathrm{~m}^{2}$, przy czym w mieście była to nieco mniejsza powierzchnia $63 \mathrm{~m}^{2}$, natomiast na wsi znacznie wyższa $81 \mathrm{~m}^{2}$. Nieco lepszą sytuacją mieszkaniową charakteryzowały się małżeństwa i związki nieformalne wychowujące 1 dziecko, ponieważ zajmowały powierzchnię $73 \mathrm{~m}^{2}$. Analogicznie i w tej kategorii gospodarstw domowych mniejszą powierzchnię mieszkalną, tj. $66 \mathrm{~m}^{2}$ dysponowały rodziny mieszkające w miastach wobec $98 \mathrm{~m}^{2}$ lokali mieszkalnych posiadanych przez gospodarstwa rodzinne na wsi. Znacząco lepsza sytuacja pod tym względem dotyczyła małżeństw i związków nieformalnych posiadających 2 dzieci na utrzymaniu. $\mathrm{W}$ tych gospodarstwach rodzinnych zajmowany metraż wynosił średnio $85 \mathrm{~m}^{2}$, przy czym $78 \mathrm{~m}^{2}$ dla rodzin mieszkających w mieście i $102 \mathrm{~m}^{2}$ na wsi. Jednak posiadanie 3 i więcej dzieci w rodzinie nie oznaczało proporcjonalnie większej użytkowanej powierzchni. Wielodzietne rodziny zajmowały średnio $91 \mathrm{~m}^{2}$ (przy czym przeciętna wielkość użytkowanej powierzchni w miastach to $79 \mathrm{~m}^{2}$, natomiast na wsi $103 \mathrm{~m}^{2}$ ). Nieco słabszą sytuacją mieszkaniową charakteryzowały się bezdzietne małżeństwa i związki nieformalne, ponieważ użytkowały średnio $69 \mathrm{~m}^{2}, \mathrm{z}$ tym że w miastach była to niższa powierzchnia użytkowa $63 \mathrm{~m}^{2}$, zaś na wsi wyższa $86 \mathrm{~m}^{2}$, względem wspomnianej powyżej średniej (GUS, 2014, s. 54). 


\section{Wzorce w krajach Europy Zachodniej}

Opracowanie i uruchomienie programu Mieszkanie Plus (Uchwała nr 115/2016 Rady Ministrów, 2016, s. 7) zostało poprzedzone analizami analogicznych programów funkcjonujących w niektórych krajach Europy Zachodniej. W związku z tym przy opracowywaniu kluczowych założeń strategiczno-programowych tego instrumentu polityki mieszkaniowej w Polsce korzystano z już sprawdzonych i prowadzonych od lat rozwiązań w innych krajach Unii Europejskiej (Gwoździewicz, Prokopowicz, 2016, s. 65). W kontekście całej UE Polska była jednym z nielicznych krajów, w których do tej pory nie był prowadzony tego typu program. Spośród krajów Unii Europejskiej najbardziej rozwinięte systemy tanich mieszkań czynszowych funkcjonują w takich krajach jak Holandia, Austria, Dania, Szwecja, Wielka Brytania i Francja. Jednak nie są to w pełni analogiczne systemy wobec rozwijanego w Polsce programu Mieszkanie Plus. Różnice występują w zakresie zastosowanych w poszczególnych krajach instrumentów, poprzez które realizowana jest pomoc publiczna, ponieważ są to przede wszystkim:

- udzielane na preferencyjnych warunkach kredyty bankowe, zwykle nisko oprocentowane,

- uproszczenia, ułatwienia w systemie fiskalnym, w tym ulgi podatkowe i gwarancje,

- budowanie mieszkań na obszarach należących do Skarbu Państwa oraz włączanie działek budowlanych do systemów budowy mieszkań czynszowych i komunalnych po cenach niższych od rynkowych lub bezpłatnie.

Funkcjonujące w innych krajach programy typu Mieszkanie Plus wspomagają rozwój społecznego budownictwa czynszowego, głównie poprzez instrumenty nisko oprocentowanych kredytów. Pomoc publiczna realizowana poprzez dopłaty do odsetek kredytów oraz gwarancje występuje m. in. w takich krajach jak Francja, Wielka Brytania, Dania, Finlandia, Austria, Irlandia i Belgia (narodowyprogram. pl, 2017). W większości krajów Zachodniej Europy globalny kryzys finansowy z 2008 roku wymusił ograniczenie stosowanej pomocy publicznej w programach wsparcia społecznego budownictwa czynszowego. W związku z tym redukcji poddano różne bezzwrotne formy subwencjonowania budownictwa mieszkaniowego, natomiast rozwijane były instrumenty preferencyjnego oprocentowania kredytów. Jednak mimo kryzysu finansowego skala pomocy publicznej w rozwiniętych krajach Europy Zachodniej w zakresie finansowania społecznego budownictwa czynszowego pozostała nadal znacząca. $Z$ drugiej strony skala negatywnych ekonomicznie zjawisk związanych z kryzysem finansowym była w tych krajach, tj. w Europie Zachodniej i w Skandynawii, znacznie mniejsza niż w krajach południa Europy, w których zastosowano znacznie większe redukcje wydatków budżetowych na cele społeczne.

W większości krajów UE, w których rozwijane są systemy wsparcia społecznego budownictwa czynszowego w ramach pomocy publicznej, coraz częściej finansowanie 
prowadzone jest na prywatnym rynku kapitałowym, a państwo dopłaca do odsetek preferencyjnych kredytów lub stosowane jest niższe od rynkowego oprocentowanie, również poprzez państwowe lub samorządowe gwarancje publiczne (narodowyprogram.pl, 2017).

\section{Istota i cele programu Mieszkanie Plus}

W związku z powyższym obecny rząd w I połowie 2016 roku opracował kluczowe założenia tego programu, a w końcówce 2016 roku rozpoczęto realizację programu Mieszkanie Plus. Pierwszym miastem, w którym w grudniu 2016 roku rozpoczęto realizację tego programu była Biała Podlaska, położona na północy województwa lubelskiego, we wschodniej Polsce. Otóż dokładnie 22 grudnia 2016 roku nastąpiło uroczyste wbicie symbolicznego szpadla na placu budowy przy ul. Jana Kazimierza w Białej Podlaskiej, czym zainaugurowano rozpoczęcie realizacji programu Mieszkanie Plus. W tym inauguracyjnym projekcie budowlanym powstaną 3 bloki ze 186 mieszkaniami, które wybudowane zostaną przez trzy regionalnie działające firmy budowlane (Tygodnik Podlaski, 2016-2017, s. 1-3). Jeżeli skala realizacji tego programu, tak jak jest planowany, będzie znacząca wobec potrzeb mieszkaniowych zgłaszanych szczególnie przez młode rodziny, to wówczas jego strategiczne, długoterminowe cele powinny zostać osiągnięte. Program Mieszkanie Plus, zgodnie z którym w okresie kilku najbliższych lat powstać ma znacząca ilość nowych, tanich w eksploatacji mieszkań czynszowych pod wynajem, powinien wedle założeń przyczynić się do poprawy życia rodzin w Polsce, szczególnie młodych rodzin, które w ten sposób uzyskałyby poprawę warunków bytowych i odpowiednio częściej dzięki temu decydowały by się na powiększenie rodziny, na posiadanie większej ilości dzieci (telewizjarepublika.pl, 2017a). Zgodnie $\mathrm{z}$ informacjami publikowanymi $\mathrm{w}$ prasie $\mathrm{w}$ kwietniu bieżącego roku pierwsze mieszkania zbudowane $\mathrm{w}$ tym programie miały być oddane do użytku pod koniec 2017 roku, a w kolejnych latach powinno nastąpić przyspieszenie procesu budowy następnych mieszkań (telewizjarepublika.pl, 2017b).

Głównym celem tego programu jest poprawa sytuacji w sektorze mieszkalnictwa w Polsce. Sytuacja ta obecnie nie przedstawia się dobrze, ponieważ w statystykach Polska na tle Europy plasuje się na ostatnim miejscu w zakresie ilości mieszkań przypadających na 1000 obywateli. Program ten w opinii wielu ekonomistów powinien w jeszcze większym stopniu przeciwdziałać w perspektywie średnio- i długoterminowej niekorzystnej tendencji zmian struktury demograficznej społeczeństwa w Polsce, tj. starzenia się społeczeństwa, niż opisany powyżej program Rodzina 500 Plus (Rodzina $500+$, pod jakimi warunkami program ma szansę na sukces?, 2015). Z drugiej strony dopiero zaplanowanie, uruchomienie i kompleksowa realizacja skorelowanych 
ze sobą kilku segmentów polityki rodzinnej zapewnić może dla polskiej gospodarki i dla Polaków osiągnięcie w przyszłości zamierzonych strategicznych celów. Według przyjętych założeń program Mieszkanie Plus powinien także przyczynić się do ożywienia wzrostu gospodarczego Polski Wschodniej. W trakcie realizacji tego programu powstanie wiele nowych miejsc pracy, w związku z czym powinna także ulec znaczącemu zmniejszeniu migracja zarobkowa obywateli z tegoż regionu Polski.

Kluczowym celem programu Mieszkanie Plus jest wybudowanie i tym samym zapewnienie lokum mieszkalnego dla młodych rodzin charakteryzujących się formułą składu osobowego określanego jako przynajmniej $2+1$. Mieszkania w ramach tego programu budowane są $\mathrm{w}$ formule średniego metrażu, tj. o powierzchni 45-75 metrów kwadratowych. Kluczowym segmentem odbiorców tych mieszkań są rodziny, których nie stać na udzielane według komercyjnych zasad, bankowe kredyty hipoteczne. Obecnie wielu Polaków, mimo tego że pracują, to jednak nie mają wymaganej przez banki komercyjne zdolności kredytowej (Domańska-Szaruga, 2015, s. 95) i nie są w stanie uzbierać niezbędnego wkładu własnego, który według normatywnych wymogów Komisji Nadzoru Finansowego stanowi już 1/5 wartości mieszkania.

Zgodnie ze strategiczno-programowymi założeniami program Mieszkanie Plus skierowany jest do osób lub rodzin, które reprezentują głównie niezamożną klasę średnią, tj. pracują, wychowują dzieci, nie należą do marginesu społecznego, są pełnoprawnymi obywatelami, posiadają pełnię praw publicznych, jednak ze względów ekonomicznych, od transformacji systemowej na początku lat 90., to zwykle osoby tej klasy społeczeństwa dźwigają na swych barkach największy relatywnie udział podatków i innych obciążeń składkowych na ZUS itd. i ze strony państwa otrzymywały zawsze najmniej bezpośredniej pomocy publicznej. Ze względu na obecnie realizowane programy polityki społecznej, wymienione powyżej dysproporcje i rozwarstwienie ekonomiczne powinny się znacząco zmniejszyć. W związku z tym program Mieszkanie Plus skierowany jest głównie do osób lub rodzin, które reprezentując powyżej zdefiniowaną niezamożną klasę średnią nie spełniają kryteriów do ubiegania się o mieszkanie komunalne, z drugiej strony poziom wynagrodzeń uzyskiwanych zwykle z pracy najemnej jest tak niski, że uniemożliwia wynajem lokum na rynku komercyjnym. Niski poziom wynagrodzeń oznacza słabą zdolność kredytową, w związku z czym osoby te mają trudności z uzyskaniem oferowanego przez banki komercyjne kredytu hipotecznego (warszawa.eska.pl, 2017).

W ramach rozwoju programu Mieszkanie Plus rząd planuje rozwijać przede wszystkim system kompleksowej organizacji procesów budowy nowych mieszkań dostępnych dla rodzin, głównie z segmentu niezamożnej klasy średniej, oferowanych w ramach systemu najmu z możliwością wykupu własności. Program ten realizowany jest początkowo przy wsparciu środków publicznych, za pomocą których inwestycje budowlane prowadzone są przez komercyjnie działające przedsiębiorstwa i firmy deweloperskie. Docelowo, sukcesywnie powinien zwiększać się udział zaangażowania rynkowego finansowania oraz refinansowania realizacji całego programu. 
Połączenie wsparcia publicznego z rynkowymi procesami realizacyjnymi polega głównie na (mib.gov.pl, 2017):

- włączeniu nieruchomości Skarbu Państwa do zasobów gruntowych lokalizacji, w których budowane są nowe mieszkania w systemie wynajmu na niekomercyjnych zasadach,

- wsparciu finansowania budowy nowych mieszkań ze środków publicznych zgromadzonych w Funduszu Inwestycyjnym Zamkniętym i udzielanych na podstawie tych środków przez Bank Gospodarstwa Krajowego Nieruchomości linii kredytowych, z których korzystają budujący mieszkania na zasadach rynkowych deweloperzy (Narodowy Program Mieszkaniowy, 2016, s. 29),

- ilościowym wzroście liczby rokrocznie oddawanych do użytku mieszkań, w wyniku czego wzrastać będzie dostępność mieszkań także dla obywateli niezamożnej klasy średniej, następować będzie aktywizacja wzrostu gospodarczego i działać będzie presja na obniżanie rynkowych cen wynajmu i zakupu mieszkań.

Zgodnie z przyjętą w 2016 roku nowelizacją polityki mieszkaniowej program Mieszkanie Plus to działanie realizowane we współpracy z samorządami, a docelowo również z innymi podmiotami, w tym spółkami Skarbu Państwa. Zgodnie ze strategiczno-programowymi celami program ten ma wypełnić lukę niedoboru mieszkań w Polsce, szczególnie w segmencie tanich mieszkań na wynajem oferowanych obywatelom niezamożnej klasy średniej. W ostatnich latach w Polsce budowanych było około 120 tysięcy mieszkań rocznie. Aby do 2030 roku dostępność mieszkań w Polsce osiągnęła poziom średniej w Unii Europejskiej (Prokopowicz, 2012a, s. 26-27), powinno być w Polsce od 2017 roku budowanych minimum 200 tysięcy mieszkań, tj. o prawie 100 tys. mieszkań rokrocznie więcej niż budowano $\mathrm{w}$ ostatnich latach. W związku z tym przed programem Mieszkanie Plus stoi wiele wyzwań i aby ten program osiągnął swój cel, powinny być zaangażowane na szerszą skalę różne podmioty publiczne i jednostki samorządu terytorialnego, a nie tylko kilka Spółek Skarbu Państwa i Bank Gospodarstwa Krajowego Nieruchomości (radio.lublin.pl, 2017).

Poza programem Mieszkanie Plus do kluczowych segmentów prowadzonej obecnie polityki mieszkaniowej zalicza się jeszcze kilka innych programów publicznego wsparcia budownictwa osiedli mieszkaniowych, domów jednorodzinnych oraz ich remontów, przeprowadzania prac termomodernizacyjnych i ich finansowania poprzez instrumenty kredytowe Banku Gospodarstwa Krajowego. Wszystkie te segmenty zdefiniowane zostały w Narodowym Programie Mieszkaniowym. Niektóre $\mathrm{z}$ nich planowane są na terminy kilkuletnie, jak np. prowadzony obecnie program „Mieszkanie dla młodych”, w ramach którego zaplanowany program wsparcia ze środków publicznych zakupu mieszkania, poprzez dopłaty do spłaty odsetek udzielanych na komercyjnych zasadach kredytów mieszkaniowych, funkcjonować ma do 2018 roku. Z drugiej strony większość kluczowych instrumentów polityki 
mieszkaniowej określonej w Narodowym Programie Mieszkaniowym zaplanowano w kilkunastoletniej perspektywie realizacyjnej do 2030 roku. Wobec powyższego, obok programu Mieszkanie Plus, do głównych segmentów prowadzonej obecnie polityki mieszkaniowej zalicza się programy (Narodowy Program Mieszkaniowy, 2016, s. 49):

- kredytowania inwestycji budowlanych realizowanych w ramach programu Mieszkanie Plus i udzielania na niekomercyjnych zasadach pożyczek oferowanych przez Bank Gospodarstwa Krajowego Nieruchomości,

- wspierania przez państwo budownictwa komunalnego i chronionego poprzez dotowanie ze środków publicznych 35-55 proc. kosztów, w tym inwestycji budowlanych prowadzonych przez samorządy terytorialne budowy lokali socjalnych, mieszkań komunalnych, noclegowni i schronisk dla bezdomnych,

- rozwoju budownictwa społecznego poprzez finansowanie ze środków publicznych dopłat do oprocentowania udzielanych przez Bank Gospodarstwa Krajowego na preferencyjnych zasadach kredytów i obligacji, z pomocą których realizowane są inwestycje budowlane prowadzone przez towarzystwa budownictwa społecznego, spółdzielnie mieszkaniowe i spółki samorządów gminnych,

- realizowany latach 2014-2018 program „Mieszkanie dla młodych”, w ramach którego wsparcie publiczne prowadzone jest poprzez dofinansowanie wkładu własnego w sytuacji zaciągania kredytu bankowego w banku komercyjnym na zakup pierwszego mieszkania lub domu jednorodzinnego przez młode osoby,

- finansowania ze środków publicznych termomodernizacji i remontów prywatnych budynków mieszkalnych oraz obiektów użyteczności publicznej,

- dotacji, którymi pokrywana jest część kosztów wydatków poniesionych na zakup materiałów budowlanych niezbędnych w procesie realizacji inwestycji w ramach budowy domów jednorodzinnych.

\section{Programy Rodzina 500 Plus i Mieszkanie Plus oraz Plan na Rzecz Odpowiedzialnego Rozwoju jako kluczowe segmenty prorozwojowej polityki gospodarczej w Polsce - Gospodarka Plus}

Opisane powyżej, kluczowe programy inwestycyjnej prorodzinnej polityki społecznej, tj. programy Rodzina 500 Plus (Gwoździewicz, Prokopowicz, 2017, s. 272-273) i Mieszkanie Plus, należą do najważniejszych segmentów prorozwojowej polityki społeczno-gospodarczej, której nadano nazwę własną program Gospodarka Plus. W marcu 2016 roku Premier Beata Szydło na konferencji prasowej w Sanoku stwierdziła, że program Gospodarka Plus jest przyszłością Polski, że dzięki temu 
programowi przyszłość ta dla obywateli Polski odczuwalnie powinna ulec poprawie (300polityka.pl, 2016). Zgodnie z przyjętymi założeniami program Gospodarka Plus jest określeniem prorozwojowej polityki społeczno-gospodarczej, której zasadniczym celem makroekonomicznym jest znacząca aktywizacja przedsiębiorczości i innowacyjności obywateli (Prokopowicz, 2016c, s. 72-73) oraz rozwoju firm i wygenerowanie znacznego przyspieszenia rozwoju gospodarczego kraju. Programy Rodzina 500 Plus i Mieszkanie Plus są kluczowe dla inwestycyjnej i prorodzinnej polityki społecznej, tj. pełnią szczególnie istotną rolę w kontekście całokształtu polityki społeczno-gospodarczej jednak nie są jedynymi ważnymi segmentami programu Gospodarka Plus. Bezpośrednimi beneficjentami programów Rodzina 500 Plus i Mieszkanie Plus są rodziny, $\mathrm{tj}$. z ekonomicznego punktu widzenia obywatele prowadzący gospodarstwa domowe. Jednak tak jak w niemal każdym programie określającym strategię rozwoju gospodarczego kraju, tak również w programie Gospodarka Plus - oprócz gospodarstw domowych - także przedsiębiorstwom przypisuje się istotną rolę w kontekście determinantów aktywizujących wzrost gospodarczy. W związku z tym w połączonych resortach Ministerstwa Rozwoju i Ministerstwa Finansów, którymi kieruje Wicepremier Mateusz Morawiecki opracowany został Plan na Rzecz Odpowiedzialnego Rozwoju. Kluczowymi podmiotami tego Planu są przedsiębiorstwa, zarówno te małe i średnie z sektora MSP, jak i te większe oraz ich finansowanie, wspieranie, promowanie innowacyjności itp. (Prokopowicz, 2016d, s. 176).

W przemówieniu wygłoszonym w fabryce Autosan Premier rządu przedstawiła zasadnicze założenia nowego programu gospodarczego rządu wpisanego w program Gospodarka Plus, który będzie także obejmować m.in. plan Wicepremiera Mateusza Morawieckiego. Przemówienie to Premier Beata Szydło wygłosiła na tle dwóch autobusów marki Autosan, z tym że jeden z modeli był egzemplarzem z przeszłości, sprzed kilkudziesięciu lat, z początków funkcjonowania tej fabryki, natomiast drugi był jego współczesnym odpowiednikiem. W ten sposób, to zestawienie obu modeli autobusów, reprezentujących zupełnie już odmienne okresy historyczne podkreślać miało medialny przekaz dotyczący rozpoczętego procesu reindustrializacji. W Sanoku wówczas Premier Beata Szydło potwierdziła wcześniejsze zapowiedzi, że przyjęty pod koniec 2015 roku przez rząd Plan na Rzecz Odpowiedzialnego Rozwoju Wicepremiera Morawieckiego koreluje się i jest elementem składowym programu Gospodarka Plus. Zgodnie z przedstawionymi założeniami Plan na Rzecz Odpowiedzialnego Rozwoju będzie realizowany nie tylko w miejscach, gdzie jest już przemysł i firmy, ale także w małych miejscowościach, które znajdują się z dala od Warszawy, w regionach o niskim stopniu uprzemysłowienia, także w województwach Polski wschodniej, tj. regionach rozwijających się w poprzednich latach znacznie wolniej od średniej rozwoju gospodarczego kraju.

Główne segmenty planu Morawieckiego, tj. Planu na Rzecz Odpowiedzialnego Rozwoju, ujęte zostały w 5 następujących hasłach: reindustrializacja, rozwój innowacyjnych firm, kapitał dla rozwoju, ekspansja zagraniczna oraz rozwój społeczny 
i terytorialny. Kluczowymi przesłankami tego planu jest aktywizacja i wparcie rozwoju przemysłu w Polsce, ze szczególnym uwzględnieniem tych gałęzi przemysłu, które oparte są na implementacji zaawansowanych rozwiązań technologicznych (Prokopowicz, 2016c, s. 73-74). Istotnym czynnikiem znacząco wpływającym na koniunkturę krajowej gospodarki jest prorozwojowa polityka kredytowa kształtowana przez funkcjonujące w Polsce banki komercyjne. Na politykę tę wpływać może Narodowy Bank Polski jako bank centralny (Dmowski, Prokopowicz, Sarnowski, 2005, s. 162) w sytuacji wykorzystania stóp procentowych i innych instrumentów polityki pieniężnej, w realizacji interwencjonizmu państwowego. $\mathrm{W}$ ramach tego interwencjonizmu mogą być także uruchamiane inne instrumenty polityki gospodarczej, których celem jest aktywizacja przedsiębiorczości i innowacyjności w określonych gałęziach gospodarki.

Otóż w ramach tak realizowanego podejścia interwencjonistycznego przyjmuje się, że bez odbudowy w Polsce przemysłu opartego na nowoczesnych technologiach Polska miałaby ograniczone możliwości, aby dogonić pod względem poziomu rozwoju gospodarczego kraje wysoko rozwinięte i na zawsze zostałaby gospodarczo krajem zależnym, krajem który wpadł w tzw. pułapkę średniego wzrostu. Zgodnie z zasadniczymi założeniami tego Planu sektor prywatny powinien inwestować $\mathrm{w}$ nowoczesne technologie, a sektor publiczny powinien te inwestycje wspierać, pobudzać, promować, ale realizować to interwencjonistyczne wsparcie tak, aby nie przeszkadzać w rozwoju sektorowi prywatnemu (Morel, Palier, Palme, 2015, s. 48). Kwestią kluczową jest to, aby sektor publiczny wspierał i kooperował, inspirował planowanie i realizację dużych projektów inwestycyjnych prowadzonych głównie przez sektor prywatny. Jest to szczególnie istotne w kwestii zaplanowania tak dużych projektów inwestycyjnych, które samodzielnie przez sektor prywatny raczej by nie zostały zrealizowane, jak np. nowoczesne duże przedsiębiorstwa wytwarzające produkty o wysokim stopniu wartości dodanej, z zaangażowaniem nowoczesnej technologii. Poza tym w krajach rozwiniętych duże projekty inwestycyjne, inspirowane i koordynowane przez sektor publiczny a realizowane głównie przez sektor prywatny rozwijane są $\mathrm{w}$ takich gałęziach gospodarki jak energetyka (elektrownie jądrowe, farmy wiatrowe, elektrownie wodne i inne) oraz inwestycje komercyjne $\mathrm{w}$ gałęziach infrastrukturalnych i komunikacyjnych, $\mathrm{w}$ tym rozwiązania z zakresu budowy infrastruktury i upowszechniania dostępu do szybkiego Internetu. Poza tym rząd w kontekście planowania i realizacji dużych projektów inwestycyjnych, powinien uwzględniać potencjał młodych wykształconych Polaków kończących uczelnie, aby zaangażować do tych projektów inwestycyjnych ten obecnie już duży potencjał kapitału ludzkiego, jaki mamy w Polsce. Chodzi o to, aby ci młodzi i wykształceni ludzie nie musieli wyjeżdżać z Polski celem znalezienia satysfakcjonującej pracy i godnego życia. Pojawia się w tym miejscu kluczowe pytanie, czy $\mathrm{w}$ ramach planowania i realizacji dużych projektów inwestycyjnych poprzez skoordynowane i skorelowane działania sektora publicznego i prywatnego nie można 
byłoby zaplanować stworzenia infrastruktury parku technologiczno-naukowego, który z udziałem firm prywatnych przekształciłby się po kilkunastu latach w coś, co można by nazwać polską „Krzemową Doliną”? Być może polska gospodarka potrzebowałaby nieco więcej czasu. Chiny potrzebowały na to 30 lat, tj. czasu w którym mała chińska wioska przekształciła się w wysoko technologiczną metropolię regionu Shenzen. Chiński sukces w tym zakresie polegał na połączeniu perspektywicznego planowania rozwoju społeczno-gospodarczego i rozpisywaniu, koordynowaniu planów inwestycyjnych w ujęciu wieloletnim, sprawnej realizacji inwestycji w ramach partnerstwa publiczno-prywatnego, z zaangażowaniem ogromnych publicznych środków finansowych, pełniących rolę dotacji dla zrealizowania wcześniej zaplanowanych inwestycji technologicznych i infrastrukturalnych (Domańska-Szaruga, Prokopowicz, 2015, s. 38).

W związku z powyższym państwo powinno inspirować i wspierać proces tworzenia polskich nowych technologii i innowacji technicznych oraz technologicznych. Dla efektywnego rozwoju polskiej gospodarki niezbędne jest tworzenie polskich, rozpoznawalnych w świecie marek i produktów. Realizowana w ten sposób polityka technologiczna stanowić powinna istotny segment prorozwojowej polityki społeczno-gospodarczej i przemysłowej kraju, której istotnym aspektem jest potrzeba odbudowy przemysłu w Polsce, przynajmniej do poziomu porównywalnego z tym, jaki występował przed 1989 rokiem w zakresie udziału przemysłu $\mathrm{w}$ krajowej gospodarce.

Aktywizacja innowacyjności i tworzenia nowoczesnych technologii powinna być integralnym, jednym $z$ istotniejszych składowych prorozwojowej polityki społeczno-gospodarczej w Polsce (Prokopowicz, 2016c, s. 73-74). Bez generowania nowoczesnych rozwiązań technologicznych i bez odbudowy przemysłu w Polsce nie mamy szans, aby dorównać pod tym względem krajom wysoko rozwiniętym, które historycznie w XX wieku wyprzedziły Polskę o 50 lat, tj. okres funkcjonowania w Polsce realnego socjalizmu. Poza tym powinniśmy w ramach ostatnio kreowanego w różnych mediach patriotyzmu gospodarczego popierać krajową wytwórczość, tj. kupować polskie produkty, w ten sposób wszyscy możemy wpływać pozytywnie na wzrost produkcji, dochodów i zatrudnienia w Polsce. W ten sposób także możemy wyrażać swój patriotyzm gospodarczy. Poza tym sami zauważamy, że polskie produkty coraz częściej charakteryzują się wysoką jakością, porównywalną z zagranicznymi lub ją przewyższającą. Uwzględniając te kwestie w naszych nawykach konsumenckich pośrednio wspieramy rodzimą przedsiębiorczość, nasz rynek pracy, przyczyniamy się do spadku bezrobocia i wzrostu dochodów w Polsce (Prokopowicz, 2012, s. 39).

W związku z powyższym, zgodnie z założeniami Planu na Rzecz Odpowiedzialnego Rozwoju Wicepremiera Morawieckiego niezbędnym jest rozwijanie instrumentów wsparcia rozwoju polskich przedsiębiorstw, w tym także wsparcia powstawania i działalności start-upów, podmiotów sektora MSP, rozwijania innowacji, przedsiębiorczości, aktywizowanie rozwijania dużych programów inwestycyjnych 
$\mathrm{w}$ ramach partnerstwa publiczno-prywatnego, co prowadzić będzie do wzrostu zatrudnienia w Polsce i wzrostu dochodów (Gwoździewicz, Prokopowicz, 2015, s. 51-52). Ważne jest, aby przy tym wspierać także polski eksport oraz wdrażanie w przemyśle nowoczesnych technologii.

\section{Podsumowanie}

Szczególnie istotnym determinantem sytuacji bytowej i materialnej obywateli jest kwestia mieszkaniowa. Od początku transformacji społeczno-gospodarczej, tj. już z początkiem lat 90 . zaczęto dostrzegać znaczące niekorzystne zmiany sytuacji mieszkaniowej, co zdeterminowane było społeczno-gospodarczymi uwarunkowaniami polityki mieszkaniowej w Polsce. Zasadniczym źródłem danych, które posłużyły w określeniu sytuacji mieszkaniowej w latach ubiegłych były wyniki narodowych spisów powszechnych, stanowiące także podstawę dla zestawień analitycznych i badań porównawczych zawartych w opracowaniach wydawanych przez Główny Urząd Statystyczny.

W związku z tym obecny rząd w I połowie 2016 roku opracował kluczowe założenia tego programu, a w końcówce 2016 roku rozpoczęto realizację programu Mieszkanie Plus. Podstawowym celem tego programu jest poprawa sytuacji w sektorze mieszkalnictwa w Polsce. Sytuacja ta obecnie nie przedstawia się dobrze, ponieważ w statystykach Polska na tle Europy plasuje się na ostatnim miejscu w zakresie ilości mieszkań przypadających na 1000 obywateli. Podobnie niekorzystnie przedstawiają się statystyki dotyczące ilości tanich mieszkań czynszowych i pod wynajem w Polsce względem krajów Zachodniej Europy.

Zgodnie z zapowiedziami Premier Beaty Szydło program Mieszkanie Plus to kolejny kluczowy segment po programie Rodzina 500 Plus (Gwoździewicz, Prokopowicz, 2017, s. 277), prorozwojowego programu społeczno-gospodarczego Gospodarka Plus. Poza tym, w odróżnieniu od programu Rodzina 500 Plus, program Mieszkanie Plus nie powinien znacząco obciążać budżetu, co jest kluczową kwestią dla finansów publicznych państwa (Topolewska, 2016, s. 14). Wspomniane powyżej programy stanowiące istotne segmenty polityki społecznej nie wyczerpują całokształtu zasadniczych składowych programu Gospodarka Plus. Z programem Gospodarka Plus skorelowane są zaplanowane i częściowo już realizowane przez rząd kolejne segmenty polityki gospodarczej w ramach planu Wicepremiera, Ministra Rozwoju i Ministra Finansów Mateusza Morawieckiego. W zakresie już zapowiedzianych do realizacji na podkreślenie zasługują programy wsparcia i aktywizacji rozwoju przemysłu technologicznego, przemysłu stoczniowego, wsparcia rozwoju przedsiębiorstw sektora MSP, wsparcia eksportu oraz innych kluczowych gałęzi sektora przemysłu polskiej gospodarki, $w$ tym także Pakiet 100 ułatwień prowadzenia 
działalności gospodarczej oraz tzw. Konstytucja dla przedsiębiorców, liberalizująca $\mathrm{w}$ wielu istotnych aspektach prowadzenie działalności gospodarczej w Polsce.

Zrealizowanie programu Mieszkanie Plus, przeprowadzone zgodnie z obecnymi zamierzeniami rządu, powinno w perspektywie do 2030 roku znacząco przybliżyć Polskę do standardów krajów Europy Zachodniej pod względem dostępności mieszkań dla obywateli, mieszkań pod wynajem i własnościowych (Cesarski, 2016, s. 58). Poza tym, biorąc pod uwagę specyfikę sektora mieszkaniowego, pojawią się kolejne, realne impulsy aktywizacji polskiej gospodarki, ponieważ sektor budowlany, mieszkaniowy to jeden $\mathrm{z}$ najistotniejszych koniunkturalnych sektorów w gospodarkach. Zgodnie z zaplanowanymi celami prorozwojowej polityki społeczno-gospodarczej obywatele w perspektywie kolejnych lat powinni zacząć odczuwać poprawę życia w Polsce i ilość młodych, wykształconych Polaków, którzy wyjeżdżają za granicę szukać godnych warunków życia, powinna wreszcie zacząć znacząco spadać. Według przyjętych założeń program Mieszkanie Plus powinien także przyczynić się do ożywienia wzrostu gospodarczego w Polsce. W trakcie realizacji tego programu powstanie wiele nowych miejsc pracy, w związku z czym powinna także ulec znaczącemu zmniejszeniu migracja zarobkowa obywateli zagranicę.

Podsumowując uruchomiony w kwietniu 2016 roku program Rodzina 500 Plus (Gwoździewicz, Prokopowicz, 2017, s. 273) znacznie zmniejsza skalę niekorzystnej społecznie i ekonomicznie relacji, tj. dotychczasowej najniższej dochodowości $\mathrm{w}$ rodzinach wielodzietnych $\mathrm{w}$ odniesieniu do średniej dla całego społeczeństwa i w porównaniu $z$ innymi typami rodzin. Program Mieszkanie Plus także powinien pozytywnie wpłynąć na zmniejszenie rozwarstwienia społecznego w zakresie sytuacji mieszkaniowej (Narodowy Program Mieszkaniowy, 2016, s. 17). Pełna realizacja tego planu powinna w perspektywie roku 2030 zrównać standardy dostępności mieszkań, szczególnie w segmencie tanich mieszkań czynszowych, do poziomu średniej w Unii Europejskiej. Obecnie jest jeszcze za wcześnie, aby obiektywnie ocenić, czy kluczowe cele polityki mieszkaniowej zostaną dzięki temu programowi zrealizowane.

\section{BIBLIOGRAFIA}

[1] BYwalec C., 2012, Ekonomika i finanse gospodarstw domowych, Wydawnictwo Naukowe PWN, Warszawa.

[2] Cesarski M., 2016, Sytuacja mieszkaniowa w Polsce lat 2002-2014. Światowy kryzys, niewiadome i szanse zamieszkiwania, Wydawnictwo SGH, Warszawa.

[3] Dmowski A., Prokopowicz D., Sarnowski J., 2005, Podstawy finansów i bankowości, Wydawnictwo Centrum Doradztwa i Informacji Difin sp. z o.o., Warszawa.

[4] Dmowski A., Prokopowicz D., Sarnowski J., 2008, Finanse i bankowość. Teoria i praktyka, Wydawnictwo Centrum Doradztwa i Informacji Difin sp. z o.o., Warszawa.

[5] Domańska-Szaruga B., 2013, Common banking supervision within the financial safety net, [w:] K. RaczKowski, F. SchNeIder (red.), The economic security of business transactions. Management In Business, Chartridge Books Oxford, Oxford. 
[6] Domańska-Szaruga B., 2015, Wybrane aspekty wykluczenia kredytowego $w$ świetle założeń zrównoważonego rozwoju, [w:] T. BoRYs, P. Rogala (red.), Zrównoważony rozwój organizacji - aspekty społeczne, Wydawnictwo Uniwersytetu Ekonomicznego, Wrocław.

[7] Domańska-Szaruga B., Prokopowicz D., 2015, Makroekonomiczne zarzqdzanie antykryzysowe, [w:] 34 Zeszyty Naukowe Uniwersytetu Przyrodniczo-Humanistycznego w Siedlcach, nr 107, Seria: Administracja i Zarządzanie (34) 2015, UPH Wydział Nauk Ekonomicznych i Prawnych, Siedlce.

[8] Gwoździewicz S., Prokopowicz D., 2015, The role and application of Keynesian macroeconomic anti-crisis theories in the context of development of the financial system in Poland, [w:] Globalization, the State and the Individual, "International Scientific Journal", Free University of Varna "Chernorizets Hrabar", Chayka, Bułgaria, Varna, nr 3(7).

[9] Gwoździewicz S., Prokopowicz D., 2016, Globalization and the process of the system and normative adaptation of the financial system in Poland to the European Union standards, [w:] Globalization, the State and the Individual, "International Scientific Journal", Free University of Varna "Chernorizets Hrabar", Chayka, Varna, Bułgaria 9007, Varna, nr 1(9).

[10] Gwoździewicz S., Prokopowicz D., 2017, The Importance Of The 500 Plus Family Program As An Impact Factor Of Family Popicy In Family Investment In Poland, [w:] "International Journal of New Economics and Social Sciences", Międzynarodowy Instytut Innowacji Nauka - Edukacja Rozwój w Warszawie, nr 1 (5).

[11] Jewdokimow M., 2011, Zmiany społecznych praktyk zamieszkiwania, Wydawnictwo Uniwersytetu Kardynała Stefana Wyszyńskiego, Warszawa.

[12] Łysoń P. (red.), 2016, Budżety gospodarstw domowych w 2015 r., Informacje i opracowania statystyczne, Główny Urząd Statystyczny, Warszawa.

[13] Mieszkanie Plus: Pierwsze lokale w 2018. Warunki normalnego życia, „Tygodnik Podlaski”, 30 grudnia 2016 - 5 stycznia 2017, nr 52 (274).

[14] Morel N., Palier B., Palme J., 2015, Polityka społeczna jako inwestycja, Wyższa Szkoła Pedagogiczna im. J. Korczaka, Warszawa.

[15] Narodowy Program Mieszkaniowy, 2016, Ministerstwo Infrastruktury i Budownictwa, Załącznik do uchwały nr 115/2016 Rady Ministrów z dnia 27 września 2016 r.

[16] Prokopowicz D. 2012b, Globalizacja, wspótpraca międzynarodowa i handel zagraniczny. Siegając w przeszłość, [w:] „Przedsiębiorstwo przyszłości”, Kwartalnik Wyższej Szkoły Zarządzania i Prawa im. Heleny Chodkowskiej, Warszawa, Nr 1 (10).

[17] Proкороwicz D., 2010, Wpływ globalnego kryzysu rynków finansowych na koniunkturę polskiej gospodarki, [w:] Zeszyty Naukowe Almamer Szkoła Wyższa z siedzibą w Warszawie, Ekonomia, Wydawnictwo Wyższej Szkoły Ekonomicznej Almamer, Warszawa, Nr 4 (61).

[18] Prokopowicz D., 2012a, Na tle struktur rynkowych Unii Europejskiej, [w:] „Przedsiębiorstwo przyszłości”, Kwartalnik Wyższej Szkoły Zarządzania i Prawa im. Heleny Chodkowskiej, Warszawa, Nr 2 (11).

[19] Prokopowicz D., 2016b, Social and economic determinants of the processes of economic globalization that shape the development of the banking system in Poland, [w:] Globalization, the State and the Individual, "International Scientific Journal", Free University of Varna "Chernorizets Hrabar”, Chayka, Varna, Bułgaria 9007, Varna 2016, nr 2(10).

[20] Prokopowicz D., 2016d, Determinanty innowacyjności i przedsiębiorczości w zakresie działalności jednostek samorzadowych wspótpracujących z lokalnymi przedsiębiorcami, [w:] „25 lat samorządności w Polsce - bilans decentralizacji władzy i zmiany gospodarczej”, Instytut Socjologii UKSW, Wydawnictwo Kontrast, Warszawa, wrzesień. 
[21] Prokopowicz D., 2016a, The importance of economic globalization in the context of the development of the financial system in Poland, [w:] "International Journal of New Economics and Social Sciences", ZN, nr 2 (4) 2016.

[22] Proкороwicz D., 2016c, Znaczenie innowacyjności w sektorze przedsiębiorstw i podmiotów systemu finansowego w Polsce w kontekście rozwoju gospodarczego kraju, [w:] J. Szabłowski (red.) „Przedsiębiorczość i innowacje w wybranych krajach Europy”, Wydawnictwo Wyższej Szkoły Finansów i Zarządzania w Białymstoku, Białystok.

[23] RODZINA 500+, pod jakimi warunkami program ma szansę na sukces?, 2015, Raport Instytutu Innowacji Społecznych im. Janusza Korczaka, Wyższa Szkoła Pedagogiczna im. J. Korczaka, Warszawa.

[24] Rogala M., 2016, Program 500+. Jak madrze zainwestować dodatkowy kapitał rodzinny, Wydawnictwo Helion, Warszawa.

[25] Topolewska M., 2016, 500+ krok po kroku Rewolucja w świadczeniach, Wydawnictwo Infor Biznes, Warszawa.

[26] Tyszka Z., 2001, Współczesne rodziny polskie - ich stan i kierunek przemian, Seria Socjologia, Wydawnictwo Naukowe UAM, Toruń.

[27] UCHWAŁA NR 115/2016 Rady Ministrów z dnia 27 września 2016 r. w sprawie przyjęcia Narodowego Programu Mieszkaniowego.

[28] Warunki życia rodzin $w$ Polsce, 2014, Informacje i opracowania statystyczne, Departament Badań Społecznych i Warunków Życia GUS, Wydawnictwo Główny Urząd Statystyczny, Warszawa.

\section{NETOGRAFIA}

[29] Kuźmiuk Z., Udało się! Na Mieszkanie plus jest już ponad 5 mld złotych, [w:] portal internetowy „Telewizja Republika”, http://telewizjarepublika.pl/udalo-sie-na-mieszkanie-plus-jest-juz-ponad5-mld-zlotych,47583.html (23.04.2017).

[30] Mieszkanie plus staje się rzeczywistościa. 186 Mieszkań w budowie, [w:] portal internetowy „Telewizja Republika", http://telewizjarepublika.pl/quotmieszkanie-plusquot-staje-sie-rzeczywistoscia186-mieszkan-w-budowie,48890.html (22.05.2017).

[31] Mieszkanie Plus w innych krajach Unii Europejskiej, [w:] Portal internetowy „Narodowy Program Mieszkaniowy, Strona informacyjna programów Mieszkanie Plus, MDM", https://narodowyprogram.pl/indywidualne-konta-mieszkaniowe/indywidualne-konto-mieszkaniowe (27.01.2017)

[32] Mieszkanie Plus: jak wynajaćc, kto dostanie, komu się należy, ceny za wynajem?, [w:] internetowy portal informacyjny „Warszawa Eska”, http://warszawa.eska.pl/newsy/mieszkanie-plus-jakwynajac-kto-dostanie-komu-sie-nalezy-ceny-za-wynajem-informator/188423 (26.07.2017).

[33] Narodowy program mieszkaniowy, [w:] Portal internetowy „Ministerstwa Infrastruktury i Budownictwa", http://mib.gov.pl/2-NPM.htm (25.05.2017).

[34] Programy, [w:] Portal internetowy „Ministerstwa Infrastruktury i Budownictwa”, http://mib.bip. gov.pl/budownictwo/programy.html (22.12.2015).

[35] RAснискі M., Sytuacja materialna polskich rodzin - bezdzietni maja najlepiej, [w:] Portal internetowy „Wynagrodzenia.pl”, za: dane GUS, http://wynagrodzenia.pl/informacje-prasowe/ sytuacja-materialna-polskich-rodzin-bezdzietni-maja-najlepiej (21.11.2014).

[36] Sовоń A., Samorządy i inwestorzy prywatni kluczem do sukcesu Mieszkania Plus, [w:] Portal internetowy „Radio Lublin”, http://radio.lublin.pl/news/artur-sobon-samorzady-i-inwestorzyprywatni-kluczem-do-sukcesu-mieszkania-plus (20.06.2017). 
[37] Szydło w Sanoku zapowiada program gospodarka i podkreśla to przyszłość Polski, [w:] Portal internetowy 300polityka, http://300polityka.pl/news/2016/03/30/szydlo-w-sanoku-zapowiadaprogram-gospodarka-i-podkresla-to-przyszlosc-polski (30.03.2016).

[38] Trudna sytuacja materialna rodzin wielodzietnych - alarmujacy raport GUS, [w:] Portal internetowy „Duża Rodzina”, http://duzarodzina.pl/aktualnosci/trudna-sytuacja-materialna-rodzinwielodzietnych-alarmujacy-raport-gus/ (11.06.2015). 